\title{
Obituary
}

\section{Dr. Peter Giles}

$\mathrm{W}$ E regret to record the death of Dr. Peter Giles, Master of Emmanuel College, Cambridge, and distinguished philologist, which took place in Cam. bridge on September 17 at the age of seventy-four years.

Peter Giles was born at Strichen, Aberdeenshire, on October 20, 1860, and after graduating at the University of Aberdeen, he went up to Cambridge as a scholar of Gonville and Caius in 1882. He was placed in the first class in both parts of the Classical Tripos and in the second class in history; and he won a number of University prizes. He was elected a fellow of Caius in 1887; but in 1890 he migrated to Emmanuel, and in 1891 was appointed reader in comparative philology in succession to Dr. Peile. In 1911 he became Master of his college. Throughout his academic career he fulfilled the many duties in College and University to which he was called, with conspicuous success by the exercise of qualities which won him the affectionate respect of all with whom he came into contact.

Giles's influence in the study of comparative philology began to be felt when the exuberant enthusiasm aroused by Max Müller's early teaching was waning under the cold breath of criticism. His "Short Manual of Comparative Philology for Classical Students" (1895) introduced a new and saner method to British scholarship. Nevertheless it was only very slowly that philology came to be regarded as anything but a highly specialised and circumscribed study, which could contribute little to the analysis of the broader aspects of cultural development which absorbed the attention of archæologist and ethnologist. Here again it was the influence of Giles and his writings, and more especially his contributions to Hastings's "Encyclopædia of Religion and Ethics" and the Cambridge Histories, that did much to restore a truer sense of balance and proportion. The brilliance and sanity of his discussion of the Aryan problem, as well as the convergence of his views towards lines which were being traced by archæological research, once more directed attention to a body of evidence which, with due recognition of its limitations, students of the origins of European culture could no longer afford to neglect.

\section{Mr. T. H. Riches}

THE death of Mr. Thomas Henry Riches, on September 19, at the age of seventy years, will be much regretted by his many scientific friends. As an undergraduate at Caius College, he was much interested in zoology, and after taking his degree in 1888 , he devoted some time at Plymouth to the study of the Nemerteans. Here he published an account of the local forms, and collected material for elucidating the embryology of Cephalothrix; though before this work could be brought to satisfy his critical and rather fastidious mind, the burden of wealth was thrust upon him and he had perforce to turn his attention elsewhere.

Throughout life, however, Riches kept in close touch with zoological developments, and when experimental heredity became prominent he embarked on breeding research with rabbits-continuing it for a number of years. Though here again he published nothing in his own name, he discovered many interesting facts which, through the medium of others, were ultimately incorporated into our standard knowledge of the geneties of this animal.

More recently, Riches undertook an investigation into the genetics of the form of achondroplasia which appears as 'bull-dog calves' in Dexter-Kerry cattle, and of the analogous monstrosities in the Scandinavian Telemark breed, and these experiments were in progress at the time of his death. Art claimed his interest as well as science, and probably many readers of NATURE will remember him as a generous benefactor to the Fitzwilliam Museum and other good causes.

ThE death has occurred in Berlin of Dr. Lydia Rabinowitch-Kempner at the age of sixty-three years. She was born at Kovno in Lithuania and studied medicine at Zurich and Berne and then in Philadelphia, where she taught in the Women's Medical College during the winter, and in the summer frequently carried out researches in Koch's laboratory in Berlin. Her first scientific work to attract attention was on the presence of non-pathogenic acid-fast bacilli in 60 per cent of the specimens of butter examined in Berlin. She then devoted her attention to tuberculosis and published articles on avian tuberculosis, spontaneous tuberculosis in domestic animals, hereditary transmission of tuberculosis in birds, etc. She also earried out researches on trypanosomiasis with Koch and on plague with Walter Kempner, another of Koch's assistants, whom she married. In 1912 she was the first woman to obtain the title of professor for scientific work. For some years prior to the antiSemitic campaign in Germany she was editor of the Zeitschrift für Tuberkulose and director of the Bacteriological Department of the Moabit Hospital, Berlin.

WE regret to announce the following deaths :

Prof. Max Cremer, emeritus professor of physiology in the University of Berlin, and formerly head of the Physiological Institute of the Veterinary College, Berlin, aged seventy years.

Prof. A. Guntz, professor of applied chemistry in the University of Algiers, and correspondant of the Academy of Sciences, Paris. 